\title{
GAMBARAN PEMAHAMAN SISWA KELAS VIII TENTANG PENCEGAHAN PERGAULAN BEBAS
}

\author{
Maudy Jendriani Indah Sari ${ }^{1}$, Ramtia Darma Putri ${ }^{2}$ \\ Universitas PGRI Palembang ${ }^{1}$ \\ Email: maudyindahsari17@gmail.com \\ Universitas PGRI Palembang ${ }^{2}$ \\ Email: tyadhuarma27@gmail.com
}

\begin{abstract}
ABSTRAK
Permasalahan yang sering terjadi pada remaja adalah kurangnya pemahaman tentang pecegahan pergaulan bebas. Penelitian ini bertujuan untuk mengetahui seberapa besar persentase gambaran pemahaman pencegahan pergaulan bebas pada siswa. Penelitian ini menggunakan metode kuantitatif deskriptif. Sampel penelitian ini berjumlah 50 orang siswa kelas VIII di SMP Negeri 4 Lais yang diambil dengan menggunakan teknik purposif sampling. Teknik pengumpulan data yang berupa angket pemahaman pencegahan pergaulan bebas dengan uji validitas 0,374 menggunakan korelasi product moment dan reliabilitas menggunakan rumus alpha cronbact 0,845. Hasil penelitian menunjukkan bahwa preventif pergaulan bebas pada siswa kelas VIII di SMP Negeri 4 Lais dalam kategori tinggi. Artinya siswa sudah cukup baik memahami tentang pergaulan bebas dan memiliki pemahaman pencegahan pergaulan bebas yang tinggi dalam kehidupan sehari-hari dan mampu melindungi diri dari pergaulan bebas.
\end{abstract}

Kata Kunci: Pemahaman siswa, pencegahan pergaulan bebas

\section{DESCRIPTION OF CLASS VIII STUDENT'S UNDERSTANDING ABOUT THE PREVENTION OF FREE ASSOCIATION}

\begin{abstract}
The problem that often occurs in adolescents is a lack of understanding of the prevention of promiscuity. This study aims to determine how much the percentage of the understanding of the prevention of promiscuity in students. This research uses descriptive quantitative method. The research sample consisted of 50 grade VIII students at SMP Negeri 4 Lais who were taken using purposive sampling technique. Data collection techniques in the form of an understanding questionnaire on the prevention of promiscuity with the validity test of 0.374 using product moment correlation and reliability using the alpha cronbact formula 0.845 . The results showed that the preventive promiscuity among class VIII students at SMP Negeri 4 Lais was in the high category. This means that students understand well enough
\end{abstract}


about promiscuity and have a high understanding of prevention of promiscuity in everyday life and are able to protect themselves from promiscuity.

Keyword: Student understanding, prevention of promiscuity

\section{PENDAHULUAN}

Peserta didik sebagai individu yang sedang berkembang cenderung menginginkan kesenangan semata tanpa mempertimbangkan akibatnya. Memasuki dewasa ini perkembangan revolusi 4.0 semakin pesat dalam perkembangan teknologi dan informasi. Revolusi industri saat ini memasuki fase keempat, dimana perkembangan ilmu pengetahuan dan teknologi yang sangat pesat memberikan dampak yang sangat besar terhadap kehidupan manusia. Dampak inipun dirasakan oleh peserta didik dalam mengakses informasi, baik dampak positif maupun dampak negatif. Dampak positifnya peserta didik dengan mudah mencari informasi mengenai ilmu pengetahuan, dan dampak negatifnya peserta didik terlena dengan kontenkonten yang seharusnya tidak mereka baca atau tonton tanpa pengawasan orang tua. Hal tersebut salah satu penyebab yang dapat mengakibatkan terjadinya pergaulan bebas jika tidak dikontrol dengan baik.

Dampak perkembangan revolusi yang dirasakan peserta didik juga dipengaruhi oleh faktor usia. Para ahli pendidikan berpendapat bahwa remaja adalah mereka yang berumur 13-18 tahun. Pada usia tersebut, seseorang sudah melewati masa kanakkanak, namun masih belum dapat dikatakan dewasa (Sumara, dkk 2017). Pergaulan bebas di Indonesia sering terjadi di kota-kota besar seperti Jabodetabek. Berdasarkan data BKKBN (Badan Kependudukan dan Keluarga Berencana Nasional) 2010, remaja yang telah kehilangan keperawanannya mencapai 51\%, sedangkan di kota lainnya seperti, Surabaya 54\%, Medan 52\%, Bandung 47\%, dan Yogyakarta $42 \%$. Dan di tahun 2013 sekitar 64 juta remaja Indonesia rentan memiliki perilaku seks bebas dan penggunaan zat tropika berbahaya. (Dikutip dari website Balitbang Hukum dan Ham 30/12/2016). 
Pergaulan bebas adalah salah satu bentuk perilaku menyimpang yang mana "bebas" yang dimaksudkan adalah melewati batas norma-norma yang ada (Abdullah, 1990:142). Masalah pergaulan ini sering kita dengar baik dalam lingkungan maupun dari media massa. Remaja adalah individu labil, yang belum mampu mengontrol emosi dan mengendalikan diri yang benar. Masalah keluarga, kekecewaan, pengetahuan yang minim, dan ajakan dari teman-teman yang bergaul bebas semakin membuat makin berkurangnya generasi muda Indonesia dalam kemajuan agama dan bangsa (Nadirah, : 2017).

\section{METODE PENELITIAN}

Penelitian ini merupakan penelitian kuantitatif dengan metode penelitian deskriptif dengan pendekatan kuantitatif. Sampel penelitian ini 50 siswa dengan pertimbangan hasil angket pemahaman pergaulan bebas yang terendah, instrumen yang digunakan dalam penelitian ini berbentuk skala likert dengan rentan skala lima. Instrumen penelitian menunjukkan tingkat validitas sebesar 0,374 dan reliabilitas alpha cronbach sebesar 0,845. Data yang terkumpul, dianalisis dengan cara menghitung skor pemahaman pencegahan pergaulan bebas yang kemudian dideskripsikan menggunakan pengkategorian sebagai berikut ini:

Tabel 1. Kategori pencegahan pergaulan bebas.

\begin{tabular}{|l|l|l|}
\hline \multicolumn{2}{|c|}{ Rentangan } & \multirow{2}{*}{ Kategori } \\
\cline { 1 - 2 } Skor & \multicolumn{1}{c|}{$\%$} & \\
\hline $69-74$ & 3 & Sangat Rendah \\
\hline $57-80$ & 2 & Rendah \\
\hline $81-86$ & 12 & Sedang \\
\hline $87-92$ & 17 & Tinggi \\
\hline $93-98$ & 16 & Sangat Tinggi \\
\hline
\end{tabular}

\section{HASIL DAN PEMBAHASAN}

Hasil dari 50 sampel penelitian, dapat diketahui bahwa pemahaman siswa kelas VIII tentang pencegahan pergaulan bebas di Negeri 4 Lais dikategorikan tinggi. Dapat dilihat pada able berikut ini: 
Tabel.2 Data pemahaman pencegahan pergaulan bebas

\begin{tabular}{|c|c|c|c|c|}
\hline No & Skor & Frekuensi & $\%$ & Kategori \\
\hline 1 & $69-74$ & 3 & $6 \%$ & Sangat Rendah \\
\hline 2 & $57-80$ & 2 & $4 \%$ & Rendah \\
\hline 3 & $81-86$ & 12 & $24 \%$ & Sedang \\
\hline 4 & $87-92$ & 17 & $34 \%$ & Tinggi \\
\hline 5 & $93-98$ & 16 & $32 \%$ & Sangat Tinggi \\
\cline { 1 - 3 } Jumlah Siswa & 50 & $100 \%$ & \multirow{2}{*}{ Tinggi } \\
\cline { 1 - 2 } Julah Skor & \multicolumn{2}{|c|}{4418} & \\
\hline \multicolumn{2}{|c|}{ Rata-rata } & $88,33 \%$ & \\
\hline
\end{tabular}

Hasil dari 50 sampel penelitian dapat diketahui bahwa gambaran pemahaman siswa kelas VIII tentang pencegahan pergaulan bebas di SMP Negeri 4 Lais dikategorikan sangat tinggi yaitu sebanyak 16 orang siswa memiliki persentase $32 \%$. Sedangkan kategori "Tinggi" dengan jumlah 17 orang siswa memiliki persentase 34\%, kategori "Sedang" dengan jumlah 12 orang siswa 24\%, kategori "Rendah" dengan jumlah 2 orang siswa dengan persentase 4\%, kategori "Sangat Rendah" dengan jumlah 3 orang siswa memiliki persentase $6 \%$. Jadi berdasarkan data diatas dapat diambil kesimpulannya bahwa pemahaman siswa kelas VIII tentang pencegahan pergaulan bebas di SMP Negeri 4 Lais memiliki rata-rata 88,36\% dengan jumlah 17 orang siswa dengan persentase 34\% dikategori "Tinggi".

Pada aspek narkoba yaitu membahas pemahaman tentang pengetahuan dan efek dari narkoba yang ditunjukkan dalam pengetahuan siswa yang memiliki pemahaman pencegahan pergaulan bebas tinggi mengetahui cukup baik apa tu narkoba dan jenisjenis narkoba begitupun dengan efek penggunaannya. Dari hasil tersebut sangat terlihat bahwa siswa sangat mampu membentengi diri dari segala bentuk pergaulan bebas semacam narkoba dan memiliki kontrol diri yang baik dalam lingkungan pergaulan.

Selanjutnya pada aspek seks bebas yaitu membahas mengenai pengetahuan dan efek dari seks bebas. Dalam pergaulan yang dapat mempengaruhi siswa, bagaimana siswa memilih pergaulan yang sehat dalam lingkungan luar maupun sekolah. Keadaan ini juga perlu dukungan dan pengawasan dari orang sekitar karena 
bagaimana pun anak mengerti dan paham tentang pergaulan bebas namun lingkungan juga membawa pengaruh besar terhadap pergaulan siswa. Namun dengan bekal pemahaman yang dimiliki anak diharapkan mampu menjadi pribadi yang berkomitmen dan iman yang teguh untuk dapat terjauh dari seks bebas. Dan yang terakshir aspek merokok yaitu bagaimana siswa mengetahui rokok dan dampak merokok yang akan merugikan diri sendiri maupun orang lain. Saat siswa sudah cukup baik memahami pergaulan dan lingkungan yang baik maka siswa dapat membentengi diri dari hal yang mencoba mempengaruhinya walaupun merokok salah satu perilaku yang dianggap wajar dikalangan.masyarakat saat ini.

Jadi dapat disimpulkan bahwa dari 50 sampel orang yang memiliki preventif pergaulan bebas dengan kategori sedang masih mampu menjaga pergaulan agar terhindar dari pergaulan bebas. Menurut Murtiwidayanti (2018:54) mengatakan bahwa remaja yang bergaul dalam lingkungan yang salah mudah terpengaruh dalam penyelahgunaan narkoba. Siswa memiliki anggapan ayng benar bahwa salah satu penyalahgunaan narkoba adalah remaja yang bergaul dalam lingkungan yang salah. Lingkungan yang sebgaian besar membawa pengaruh narkoba pada mereka.

Adapula pendapat menurut Hidayati (2012:18) mengemukakan bahwa responden yang memiliki upaya pencegahannya baik terhadap penyalahgunaan narkoba sebagian besar memiliki pengetahuan yang tinggi tentang penyalahgunaan narkoba, begitupun sebaliknya responden yang uapaya pencegahannya kurang baik terhadap penyalahgunaan narkoba sebgaian besar memiliki pengetahuan yang rendah tentang penyalahgunaan narkoba. Hasil penelitian ini juga sesuai dengan hasil penelitian terdahulu. Yang dilakukan oleh Hidayati dan Indarwati dengan judul Gambaran pengetahuan dan upaya pencegahan terhadap penyalahgunaan narkoba pada remaja di SMK Negeri 2 Seragen Kabupaten tahun 2019. Berdasarkan hasil kesimpulan penelitian di SMK 2 Seragen, bahwa responden di SMK Negeri 2 Seragen memiliki pengetahuan yang tinggi terhadap penyalahgunaan narkoba, dan responden di SMK Negeri 2 Seragen memiliki upaya pencegahan yang baik terhadap penyalahgunaan narkoba. Persamaan dengan peneliti mengetahui gambaran dan 
upaya pencegahan, menggunakan kuesioner atau angket. Perbedaannya adalah karakteristik berdasarkan jenis kelamin pada remaja di SMK Negeri 2 Seragen.

Selanjutnya dnegan judul Gambaran tingkat pengetahuan tentang bahaya seks bebas pada siswa kelas XI di SMA Negeri 1 Gamping Yogyakarta. Dari hasil penelitian yang dilakukan Asrianingtyas pada tahun 2018 diperoleh maka dapat disimpulakan bahwa tingkat pengetahuan siswa kelas XI di SMAN 1 Gamping Yogyakarta karakteristik responden paling tinggi pada jenis kelamin perempuan sebanyak 94 respunden (74\%), sedangkan berdasarkan tingkat pengetahuan yaitu tingkat pengetahuan baik sebanyak 85 responden $(66 \%)$. Persamaan dengan peneliti sama-sama menelitigambaran tingkat pengetahuan tentang bahaya seks bebas dengan penelitisn deskriptif metode kuantitatif. Perbedaannya meneliti di SMAN 1 Gamping Yogyakarta dan di SMP Negeri 4 Lais.

Kemudian dengan judul Upaya pencegahan penyalahgunaan narkoba dan seks bebas serta peningkatan kemampuan koping remaja berbasis kelompok sebaya di smp dan sma di jatinangor yang dilakukan oleh Suryani dkk tahun 2014. Hasil dari kegiatan ini dapat disimpulkan bahwa kegiatan ini sangat berguna dalam rangka mencegah terjadinya penyalahgunaan narkoba dan seks bebas bagi remaja di jatinangor. Persamaan dengan peneliti sama-sama mencegah penyalahgunaan narkoba dan seks bebas. Perbedaan peneliti menggunakan metode kuantitatif untuk memperoleh dimana range pencegahan pada siswa

\section{KESIMPULAN}

Berdasarkan hasil dari penyebaran angket preventif pergaulan bebas pada siswa SMP Negeri 4 Lais berada pada kategori tinggi. Serta saran dalam penelitian ini agar siswa kelas VIII yang sudah memiliki preventif pergaulan bebas yang sangat tinggi untuk dapat terus mempertahankannya, dan yang masih berada dibawah kategori tinggi untuk selalu memperbanyak pengetahuan mengenai pergaulan bebas agar terhindar dari perilaku yang merugikan diri sendiri maupun orang lain. 


\section{DAFTAR PUSTAKA}

Abdullah, Y. 1990. Bahaya Pergaulan Bebas. Jakarta: Media Dakwah.

Asrianingtyas, Ayu. 2018. Gambaran Tingkat Pengetahuan Tentang Bahaya Seks Bebas pada Siswa Kelas XI di SMAN 1 Gamping Yogyakarta. Universitas Yogyakarta.

Hidayati, P. E. dan Indarwati. 2012. Gambaran Pengetahuan dan Upaya Pencegahan Terhadap Penyalahgunaan Narkoba pada Remaja di SMK Negeri 2 Sragen Kabupaten Sragen. Gaster, Vol.9, No.1.

Hidayati, P. E. dan Indarwati. 2012. Gambaran Pengetahuan dan Upaya Pencegahan Terhadap Penyalahgunaan Narkoba pada Remaja di SMK Negeri 2 Sragen Kabupaten Sragen. Gaster, Vol.9, No.1. Https://www.balitangaham.go.id/detailpost/waspadai-pergaulan-bebas-bagigenerasi-bangsa

Murtiwidayanti, S.Y. 2018. Sikap dan Keperdulian Remaja dalam Penanggulangan Penyalahgunaan Narkoba. Jurnal PKS. Vol. 17 hal 44-60

Nadirah, Si. 2017. Peranan Pendidikan Dalam Pencegahan Pergaulan Bebas Anak Usia Remaja.Desember Vol. 9, No. 2. Hal 309-351

PKBI Pemerintah Kota Palembang (2007). Napza. Palembang PKBI

Safitri, dkk. 2013. Faktor-Faktor Yang Mempengaruhi Perilaku Merokok Pada Remaja. Journal Of Psycology. Vol.18, No.1.

Suryani, dkk. 2014. Upaya Pencegahan Penyalahgunaan Narkoba dan Seks Bebas Serta Peningkatan Kemampuan Koping Remaja Berbasis Kelompok Sebaya di SMP dan SMA di Jatinangor. 2014. Jurnal Aplikasi Ipteks Untuk Masyarakat. Vol.3 No.2. Hal 105-108. 